\title{
Perspective \\ OPALS: A New Osimertinib Adjunctive Treatment of Lung Adenocarcinoma or Glioblastoma Using Five Repurposed Drugs
}

\author{
Richard E. Kast ${ }^{1, *(D)}$, Marc-Eric Halatsch ${ }^{2}$ and Rafael Rosell ${ }^{3}$ \\ 1 IIAIGC Study Center, Burlington, VT 05408, USA \\ 2 Department of Neurosurgery, Cantonal Hospital of Winterthur, 8400 Winterthur, Switzerland; \\ marc-eric.halatsch@ksw.ch \\ 3 Dr. Rosell Oncology Institute (IOR), Quirón-Dexeus University Institute, 08028 Barcelona, Spain; \\ rrosell@oncorosell.com \\ * Correspondence: richarderickast@gmail.com
}

Citation: Kast, R.E.; Halatsch, M.-E.; Rosell, R. OPALS: A New Osimertinib Adjunctive Treatment of Lung Adenocarcinoma or Glioblastoma Using Five Repurposed Drugs. Cells 2021, 10, 1148. https://doi.org/ 10.3390/cells10051148

Academic Editor: Silvia La Monica

Received: 8 February 2021

Accepted: 7 May 2021

Published: 10 May 2021

Publisher's Note: MDPI stays neutral with regard to jurisdictional claims in published maps and institutional affiliations.

Copyright: (c) 2021 by the authors. Licensee MDPI, Basel, Switzerland. This article is an open access article distributed under the terms and conditions of the Creative Commons Attribution (CC BY) license (https:/ / creativecommons.org/licenses/by/ $4.0 /)$.

\begin{abstract}
Background: Pharmacological targeting aberrant activation of epidermal growth factor receptor tyrosine kinase signaling is an established approach to treating lung adenocarcinoma. Osimertinib is a tyrosine kinase approved and effective in treating lung adenocarcinomas that have one of several common activating mutations in epidermal growth factor receptor. The emergence of resistance to osimertinib after a year or two is the rule. We developed a five-drug adjuvant regimen designed to increase osimertinib's growth inhibition and thereby delay the development of resistance. Areas of Uncertainty: Although the assembled preclinical data is strong, preclinical data and the following clinical trial results can be discrepant. The safety of OPALS drugs when used individually is excellent. We have no data from humans on their tolerability when used as an ensemble. That there is no data from the individual drugs to suspect problematic interaction does not exclude the possibility. Data Sources: All relevant PubMed.org articles on the OPALS drugs and corresponding pathophysiology of lung adenocarcinoma and glioblastoma were reviewed. Therapeutic Opinion: The five drugs of OPALS are in wide use in general medicine for non-oncology indications. OPALS uses the anti-protozoal drug pyrimethamine, the antihistamine cyproheptadine, the antibiotic azithromycin, the antihistamine loratadine, and the potassium sparing diuretic spironolactone. We show how these inexpensive and generically available drugs intersect with and inhibit lung adenocarcinoma growth drive. We also review data showing that both OPALS adjuvant drugs and osimertinib have data showing they may be active in suppressing glioblastoma growth.
\end{abstract}

Keywords: EGFR; NSCLC; osimertinib; EGFR; repurposing; cancer stem cells; glioblastoma

\section{Introduction}

OPALS is a simple repurposed drug adjuvant regimen to osimertinib (Tagrisso ${ }^{\circledR}$ ), aiming to retard metastatic non-small cell lung cancer's (NSCLC) growth. It may have applicability particularly as an adjuvant to osimertinib, and in other cancers, such as glioblastoma (GB). The five OPALS adjuvant drugs are cyproheptadine, pyrimethamine, azithromycin, loratadine, and spironolactone.

Although none of the five adjuvant drugs are currently used individually to treat cancer, they all have a preclinical sound rationale and database evidence for selective cytotoxicity to NSCLC cells. Some have preliminary clinical evidence, as well. This data is reviewed here, and it is shown how the OPALS drugs intersect with NSCLC pathophysiology to inhibit its growth. All the OPALS drugs have well-established safety records when used individually in their general medicine, non-oncology roles. General medicine physicians worldwide are familiar with all the OPALS adjuvant drugs when used in their non-oncology roles. 
We reviewed core aspects NSCLC and GB growth drive and then searched the entire FDA and EMA pharmacopoeia for already-approved drugs that have data indicating they may inhibit one or another of those growth drives. Selection criteria for the OPALS augmentation regimen included (i) particularly low-risk for unpleasant side effects-this was the primary criterion, (ii) clear physiological intersection with a growth-driving element previously identified, and (iii) our clinical familiarity with the candidate drug in its non-oncology general medical role. OPALS was designed to be applicable with osimertinib as the primary treatment, with the intent to delay resistance development by increasing osimertinib's lethality or growth suppression. Other adjuvant regimens might be more effective but at the cost of a greater risk of adverse events.

More aggressive cancer treatment adjuvant systems using repurposed drugs, such as the ten-drug CUSP9v3 regimen for recurrent GB, may be more effective in the anticancer role but that comes with an attendant increase in side effect burden [1-4]. As in Palmer et al., "the 50 years old hypothesis that a curative cancer therapy can be constructed on the basis of independently effective drugs having non-overlapping mechanisms of resistance, without synergistic interaction, which has immediate significance for the design of new drug combinations" [5]; accordingly, OPALS.

OPALS is part of the repurposing movement that aims to understand the deeper pathophysiology of malignant cell growth, then look to already established drugs that might, by their primary attribute for which they are known and used or by their lesserknown ancillary attributes, intersect with the cancer's growth mechanisms so as to inhibit them [6]. Thus, Section 3 below lists data on such intersections of the anti-allergy antihistamine cyproheptadine, the antibiotic azithromycin, the anti-protozoal pyrimethamine, the antihistamine loratadine, and the potassium-sparing diuretic spironolactone. Table 1 lists selected pharmacologic attributes of the OPALS drugs. Section 2 below is a brief introduction to osimertinib.

Table 1. Basic pharmacological attributes of the OPALS drugs, cyproheptadine, pyrimethamine, azithromycin, and spironolactone. T1/2 is the elimination half-life. References in text. All the OPALS drugs have empirical evidence of NSCLC and GB growth inhibition from preclinical studies.

\begin{tabular}{|c|c|c|c|}
\hline Drug & $\mathrm{T} 1 / 2$ & Plasma Level & OPALS Function \\
\hline Cyproheptadine & $16 \mathrm{~h}$ & $\begin{array}{l}33 \mathrm{microg} / \mathrm{L} \text { av } \\
669 \mathrm{microg} / \mathrm{L} \max \end{array}$ & $\begin{array}{c}\text { anticholinergic, Bcl-2 } \\
\text { inhibition, antihistamine, }\end{array}$ \\
\hline Pyrimethamine & $4 \mathrm{~d}$ & 500 microg/L & DHFR inhibition, \\
\hline Azithromycin & $2-3 d$ & $31 \mathrm{mg} / \mathrm{L}$ & $\begin{array}{l}\text { MMP-9 reduction, autophagy } \\
\text { inhibition }\end{array}$ \\
\hline Loratadine & $8 \mathrm{~h}$ & $30 \mu \mathrm{g} / \mathrm{L}$ & lysosomal leakage \\
\hline $\begin{array}{l}\text { Spironolactone } \\
\text { canrenone }\end{array}$ & $\begin{array}{c}2 \mathrm{~h} \\
17 \mathrm{~h}\end{array}$ & $140 \mathrm{microg} / \mathrm{L}$ & $\begin{array}{l}\text { EGFR transactivation DNA } \\
\text { repair inhibition }\end{array}$ \\
\hline
\end{tabular}

OPALS drugs are here hypothesized to be a generalizable adjuvant, but not alone as a primary treatment regimen, across several different cancers. OPALS was also designed particularly with osimertinib as a primary drug in mind but would be compatible with other primary treatments.

Osimertinib is FDA and EMA-approved for use in epidermal growth factor receptor (EGFR) mutated NSCLC [7]. However, as we review below, osimertinib has shown growth retardation effects also in GB and EGFR non-mutated NSCLC.

\section{Osimertinib}

Osimertinib is a third-generation, irreversible tyrosine kinase inhibitor of EGFR, EMA and FDA-approved to treat EGFR-T790M mutated NSCLC. It irreversibly binds to the EGFR kinase domain at the cysteine-797 residue in the ATP binding site, thereby blocking signaling activity [8]. A phase 3 trial (FLAURA) in EGFR T790M-mutated NSCLC compared first-line osimertinib $80 \mathrm{mg}$ once daily to standard-of-care gefitinib $250 \mathrm{mg}$ or erlotinib 
$150 \mathrm{mg}$ once daily. The trial showed longer progression-free survival with osimertinib than with gefitinib or erlotinib. Median overall survival was 39 months in the osimertinib group and 32 months with gefitinib or erlotinib $[8,9]$. Resistance to osimertinib eventually develops, within a median of 19 months $[7,10]$. Importantly for the OPALS regimen, osimertinib has other kinase inhibition targets beyond EGFR, as reviewed below.

Although compared to other EGFR inhibitors, osimertinib possesses superior blood brain barrier penetration, little clinical evidence of its potential in GB is available [11,12]. An enduring puzzle in clinical GB research has been the robust data showing that EGFR, mutated or just EGFR overexpressed, commonly drives growth in both NSCLC and GB, yet older, non-osimertinib EGFR inhibitors such as erlotinib and gefitinib anti-EGFR treatments commonly benefit in NSCLC, but have utterly failed to benefit in GB [13]. An EGFR mutation, EGFRvIII is commonly found in GB and osimertinib inhibits this with an IC50 $<100 \mathrm{nM}$, and in a preclinical study, osimertinib inhibited EGFRvIII-positive GB growth In Vitro and in an orthotopic xenograft model [14]. Thus, an osimertinib clinical trial in GB - with or without OPALS adjuvant-would be eminently worthwhile.

In principle, when osimertinib is used to treat EGFR amplified or EGFR mutated NSCLC, such resistance evolves via:

- Multiple further EGFR mutations in EGFR T790M-positive NSCLC during osimertinib that increase the IC50 of osimertinib [15];

- NSCLC that survives initial EGFR inhibitor treatment with either gefitinib or osimertinib, commonly do so through development of EGFR-independent activation of signal transducer and activator of transcription 3 (STAT3) and Src- YES-associated protein 1 (YAP1) signaling [16,17];

- Transformation to squamous or small-cell lung cancer that is not dependent on EGFR for growth [18];

- Evolution of parallel, growth-driving RTKs, including AXL, EGFR family members, and insulin growth factor 1 receptor, MET amplification, BRAF fusions, ALK fusions, Kras mutations and RET fusions [18-20];

- Amplification of EGFR wild-type alleles conferring resistance to osimertinib [21], schematically depicted in Figure 1.

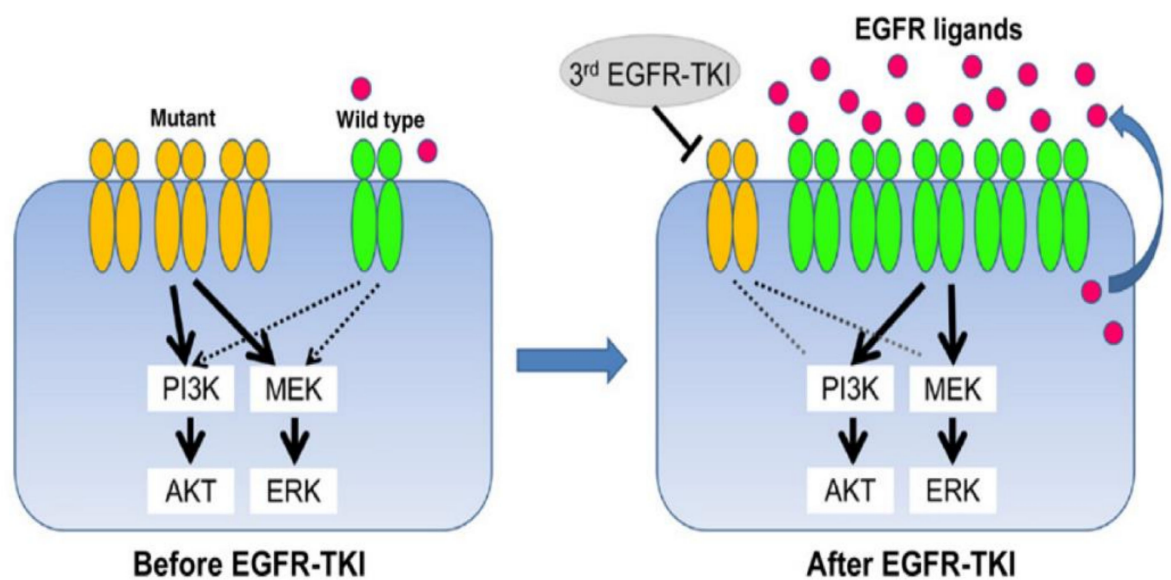

Figure 1. Schematic showing escape from osimertinib growth inhibition by increasing expression of non-mutated EGFR. References in text.

As an example of potential circumvention of osimertinib resistance, co-targeting EGFRT790M with osimertinib plus STAT3/Src with a non-marketed, nonpeptidic small molecule, STAT3 inhibitor aminocarbonyl-amino-5-4-fluorophenyl-3-thiophenecarboxamide, was synergistic in two EGFR-mutant NSCLC cell lines-PC9 harboring EGFR exon 19 deletion, E746-A750, and H1975 harboring both sensitizing L858R and resistant T790M mutations [16]. 
Clinical trials with osimertinib or other EGFR tyrosine kinase inhibitors plus Src/YAP1 inhibitors or repurposing drug regimens like OPALS are needed with the aim of overcoming or circumventing adaptive resistance mechanisms. We believe that co-treatment with OPALS or other adjuvants could circumvent or delay some of the wide array of osimertinib resistance development paths.

In addition to good brain tissue levels and inhibition of several mutated EGFRs, further benefits of osimertinib are: (A) it may be noted that osimertinib, at least partially, reverses $\mathrm{ABCB} 1$ and $\mathrm{ABCG} 2$ export of intracellular chemotherapeutic drugs like doxorubicin or temozolomide [22,23]. (B) As an example of osimertinib's non-EGFR targets, osimertinib inhibited EGFR-negative GB cells by blocking MAPK-interacting kinases and preventing eukaryotic translation initiation factor 4E (eIF4E) phosphorylation [24].

\section{The OPALS Medicines}

\subsection{Cyproheptadine}

Although cyproheptadine is known as a potent antihistamine drug active at $\mathrm{H} 1$ receptor, in continuous use since the 1940s, it has multiple other inhibitory receptor bindings. These are listed in Table 2 [25]. With high inhibitory activity at serotonergic receptors 5HT2a, 5HT2b, and 5HT2c, cyproheptadine is also commonly called an anti-serotonergic drug. Cyproheptadine, $24 \mathrm{mg}$ daily, normalized Cushing patient pulsatile cortisol in those without a pituitary adenoma [26]. Although there are more effective medicines in this role, cyproheptadine does increase appetite [27].

Table 2. Inhibitory binding of cyproheptadine at histaminic $(\mathrm{H})$, muscarinic $(\mathrm{M})$, serotonergic $(5 \mathrm{HT})$, and dopamine (D) receptors.

\begin{tabular}{cc}
\hline Receptor & Ki nM \\
\hline H1 & 0.06 \\
M1 & 12 \\
M2 & 7 \\
M3 & 12 \\
M4 & 8 \\
M5 & 12 \\
5HT1a & 59 \\
5HT2a & 1.7 \\
5HT2b & 1.5 \\
5HT2c & 2.2 \\
D3 & 8 \\
\hline
\end{tabular}

Cyproheptadine inhibited hepatocellular carcinoma (HCC) cell growth In Vitro with an IC50 of 44 microM [28]. Remissions of HCC with cyproheptadine have been reported by different groups $[29,30]$. A retrospective review of HCC patients of all stages showed decreased mortality in those who received palliative cyproheptadine [31]. A similar review of bladder cancer showed similar reduced mortality in those using cyproheptadine [32]. Sorafenib plus cyproheptadine-treated advanced HCC patients had a median survival of 11 months compared to 5 months in a matched HCC group on sorafenib alone [33].

Cyproheptadine inhibits In Vitro and xenograft growth of mantle lymphoma cells [34]. In mouse models of myeloma, cyproheptadine demonstrated inhibitory activity via cyclin D inhibition, inducing G0 arrest with subsequent apoptosis in the myeloma cells [35].

Regression of carcinoid tumors was seen in two of seven patients given cyproheptadine [36]. Others found symptomatic carcinoid improvements but no carcinoid regressions from cyproheptadine at maximum tolerable doses that ranged from 12 to $48 \mathrm{mg}$ daily $[37,38]$. Of particular note, recent In Vitro studies demonstrated good cytotoxicity of cyproheptadine to GB cells with an IC50 of 95 microM [39].

NSCLC expresses the most proteins related to choline uptake, synthesis, transport, and degradation of acetylcholine [40]. Both nicotinic and muscarinic acetylcholine receptors 
are present on NSCLC and both have a large database showing agonism at these receptors form part of NSCLC's growth drive [41-43].

Cyproheptadine inhibited urothelial carcinoma cells' growth In Vitro and in a xenograft model [44]. Cell cycle arrest followed c-Myc, induction of p21 and p27, and the stabilization of Retinoblastoma protein expression [44]. Cyproheptadine decreased expression of anti-apoptotic proteins Bcl-2, Mcl-1, and XIAP and suppressed AKT activation in myeloma cells by limiting its export from nucleus [45].

Histamine signaling at the $\mathrm{H} 1$ receptor is a worthwhile target to inhibit in both GB and NSCLC. Histamine signaling at $\mathrm{H} 1$ has been a documented mitogen in GB for over 50 years [46-51].

Muscarinic acetylcholine receptors were particularly upregulated in human GB where the tumor is invading the surrounding brain. Furthermore, elevated expression of muscarinic receptors on GB biopsy material was associated with shorter patient survival [52]. A similar study in NSCLC found a similar association only for nicotinic acetylcholine receptors [53]. Therefore, cyproheptadine may be an ideal and simple adjuvant to standard GB or NSCLC treatments.

$\mathrm{H} 1$ signaling enhances proliferation of NSCLC cells [54]. An oddity of H1 agonism is that this usually results in upregulation of muscarinic receptors [55-57]. Therefore, since cyproheptadine is particularly strong at inhibition of both $\mathrm{H} 1$ and muscarinic receptors, it might be the ideal augmentation drug in NSCLC.

\subsection{Azithromycin}

The currently marketed macrolide antibiotics, erythromycin, clarithromycin, and azithromycin, exert their antibacterial effects by reversibly binding to the $50 \mathrm{~s}$ subunit of the bacterial ribosome. Basic pharmacokinetics of azithromycin are listed in Table 3.

Table 3. Azithromycin level after a single $500 \mathrm{mg}$ oral dose. References in text.

\begin{tabular}{cccc}
\hline Post-Dose & Brain Microg/g & CSF Microg/mL & Serum Microg/mL \\
\hline $24 \mathrm{~h}$ & $2.63+/-2.58$ & $<0.015$ & $0.031+/-0.044$ \\
$48 \mathrm{~h}$ & $3.64+/-3.81$ & $<0.015$ & $0.016+/-0.011$ \\
$72 \mathrm{~h}$ & $0.74+/-0.37$ & $<0.015$ & $0.012+/-0.005$ \\
$96 \mathrm{~h}$ & 0.41 & $<0.015$ & 0.008 \\
\hline
\end{tabular}

Chu et al. studied advanced NSCLC (both adeno and squamous) given paclitaxel and cisplatin with and without low dose azithromycin $(500 \mathrm{mg} /$ day on days 1 to 5 of 28 day cycle). Those with azithromycin had marginal but unequivocal benefit in progression free and overall survival [58].

Mucosa-associated lymphoma patients were given oral azithromycin $1500 \mathrm{mg}$ once weekly, four times a month as sole treatment. Of 16 patients treated, two had a complete remission and two experienced partial remissions [59]. Resistance to the cyclin-dependent kinase (CDK4 and CDK6) inhibitor palbociclib derives from its sequestration in lysosomes in triple negative breast cancer cells [60]. Reasoning that azithromycin concentrates in lysosomes, increasing their $\mathrm{pH}$, they treated CDK4/6 inhibitor resistant TNBC cells with azithromycin that did indeed convert them to palbociclib sensitive [60].

In colon adenocarcinoma cells, azithromycin potentiated In Vitro induction of apoptosis by tumor necrosis factor-related apoptosis-inducing ligand (TRAIL) via autophagy inhibition [61]. Autophagy inhibition was also the postulated mode of action (MOA) for azithromycin cytotoxicity in squamous carcinoma cells, but this occurred only under nutrient-starved culture conditions [62]. Simultaneously targeting two major related intracellular protein degradation systems, such as the ubiquitin-proteasome with bortezomib together with autophagy-lysosome inhibition with azithromycin, enhances apoptosis in multiple myeloma cells that were resistant to either alone [63]. Temozolomide exposure induces a protective autophagy in glioma cells [64]. 
Azithromycin inhibited A549 lung tumor growth and tumor-related angiogenesis in a murine xenograft NSCLC model [65]. Azithromycin specifically reduced matrix metalloproteinase-9 (MMP-9) mRNA and protein levels in LPS exposed monocytic THP-1 cells. [66]. MMP-9 is part of a suite of tissue degrading enzymes active in facilitating malignant cell invasion of surrounding tissue. Increased serum MMP-9 activity correlated with advanced NSCLC, shorter survival and presence of distant metastasis [67]. MMP-9 is similarly active in promoting GB growth and invasion [68,69].

After a single preoperative oral dose of $500 \mathrm{mg}$ azithromycin in humans, lung tissue contained 3.10 micrograms/g at $24 \mathrm{~h}, 2.55$ micrograms/g at $72 \mathrm{~h}$, and 3.13 micrograms/g at $120 \mathrm{~h}$, as shown in Table 3 [70].

\subsection{Pyrimethamine}

Pyrimethamine is a 248 Da lipophilic drug used to treat malaria for over 50 years and continues in this role today in 2021. It inhibits human dihydrofolate reductase (DHFR) [71,72]. Pyrimethamine's Ki $=38 \mathrm{nM}$ at DHFR is comparable to that of methotrexate, $\mathrm{Ki}=2.3 \mathrm{nM}$, folinic acid $\mathrm{Ki}=320 \mathrm{nM}$, and folic acid $\mathrm{Ki}=830 \mathrm{nM}$ [71,72]. As with folate, to be active, methotrexate (MTX) must be retained within the cell; to be retained in cells, both MTX and folate must become polyglutamated.

DHFR catalyzes NADPH-dependent reduction of 7,8-dihydrofolate to 5,6,7,8tetrahydrofolate. MTX is a high affinity inhibitor of DHFR, commonly used in treating several cancers, that blocks DNA synthesis by disrupting the metabolism of methionine and the synthesis of S-adenosyl-methionine, purines, and thymidylate. Thymidine synthetic pathway depends on the methylation of deoxyuridine, the methyl donor being 5 , lO-methylenetetrahydrofolate [72,73].

Since half of pyrimethamine-treated people will develop readily reversible bone marrow suppression, blood monitoring is required [73,74]. Of great interest in treating GB or brain metastases from breast or lung cancer is the unusual property of pyrimethamine to be concentrated in the brain at several times greater than plasma levels [75].

Reduced cellular accumulation is one of the determinants of resistance to both lipophilic antifolates, such as pyrimethamine, and hydrophilic antifolates, such as MTX. Cancer cell resistance to lipophilic antifolates seems to develop more readily than MTX due to differences in mechanism of intracellular retention. MTX is retained intracellularly by polyglutamination. Pyrimethamine is retained by its lipophilicity, but also readily exported by P-gp [72,76].

Moreover, resistance to lipophilic antifolates occurs by an increase in folate accumulation with resultant expansion of the intracellular folylpolyglutamate pool, in turn resulting in increased functioning folate competition with the nonfunctional lipophilic antifolate [76].

Table 4 lists characteristic changes seen in mammalian cells that are associated with reduced cytotoxicity of pyrimethamine. Note the dramatically increased glucose requirement associated with becoming pyrimethamine-resistant [76]. Clinically, this may work in our favor, even in the absence of direct pyrimethamine cytotoxicity.

Table 4. Characteristic changes seen in mammalian cells that are associated with reduced cytotoxicity of pyrimethamine.

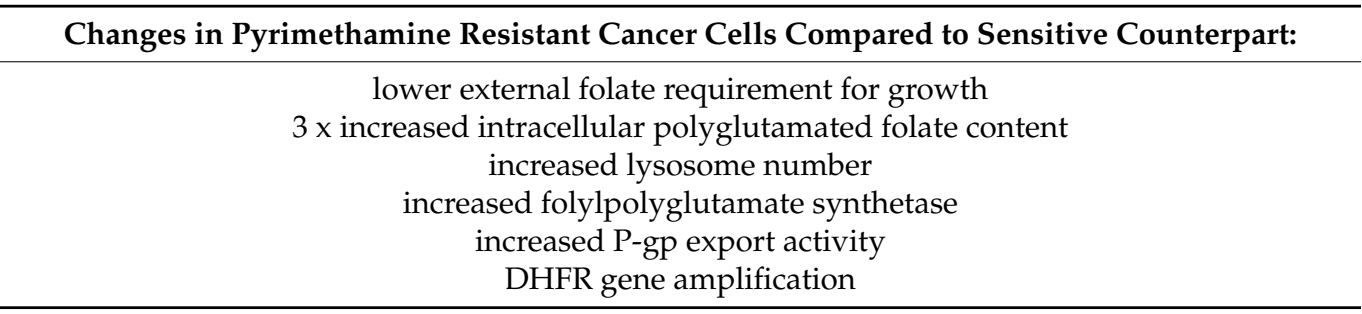

The risks of side effects with pyrimethamine are difficult to evaluate because pyrimethamine is rarely given alone when used as an antibiotic in treating malaria or 
Toxoplasmosis. Bone marrow suppression, rash, and diarrhea are not uncommon (10\% to $20 \%$ ). These are readily reversible with dose reduction and/or folinic acid rescue [74].

In an acute myelogenous leukemia model, pyrimethamine was more effective in inhibiting growth than was MTX. In Vitro proliferation was reduced 2.5-fold at $0.1 \mu \mathrm{M}$ and 12.7-fold at $0.5 \mu \mathrm{M}$ [77]. Several patients with polycythaemia rubra vera and with essential thrombocythemia were successfully controlled with pyrimethamine, reported in 1987 [78].

It is unclear why early reports in the 1970s of successful pyrimethamine treatment ( $2 \mathrm{mg} / \mathrm{kg} /$ day for 7 days) of meningeal recurrence of acute lymphoblastic leukemia in children have not been followed up, or why such use is currently rare to non-existent [79]. Pyrimethamine in combination with thioguanine, vincristine, and dexamethasone was only partially effective in adult acute lymphocytic leukemia [80]. Adding pyrimethamine to daunorubicin, cytosine arabinoside and thioguanine failed to prevent meningeal involvement in adult acute nonlymphocytic leukemia [81].

\subsection{Loratadine}

Loratadine is an old antihistamine, of unsurpassed safety, sold over-the-counter (i.e., without need for prescription) in many jurisdictions around the world. Perhaps most importantly for loratadine use in melanoma, empirically, epidemiological study revealed better survival in melanoma patients who co-incidentally were heavy users of loratadine in the anti-allergy role [82]. This loratadine effect may not be cancer type-specific, in that a similar benefit was seen in an epidemiological study of loratadine users with breast or ovarian cancer [82-84].

Loratadine is a cationic amphiphilic drug, where amphiphilic refers to drugs with hydrophobic parts and hydrophilic sites within the same molecule [85,86]. As such, cationic amphiphilic drugs such as loratadine tend to accumulate at the luminal lysosome membrane, with consequent inhibition of acid sphingomyelinase and other lysosomal lipases [87]. The resultant leak of lysosomal contents into cytosol leads to cell death if the leak is severe enough $[85,86]$. Such a loratadine-mediated lysosomal leak as a cause of cell death was demonstrated in chronic lymphocytic leukemia [88].

Loratadine sensitized bladder and oral squamous cell carcinoma cells to microtubule disrupting drugs $[89,90]$. Of note, it is the invasive subset of GB cells that are particularly vulnerable to lysosomal membrane destabilization [91].

\subsection{Spironolactone}

Spironolactone is a cheap potassium-sparing diuretic used worldwide to treat hypertension and heart failure. It entered clinical practice in the 1950s. The primary action in its most common use is to block activation of the mineralocorticoid receptor (MR). Spironolactone causes a natriuretic diuresis by preventing aldosterone stimulation of the MR [92]. Spironolactone is also used in general medicine to treat acne, hair loss, and polycystic ovarian syndrome and hirsutism in women [93]. Spironolactone crosses the intact blood brain barrier at about $50 \%$ of plasma levels [94,95].

Canrenone is an active metabolite of spironolactone with full MR antagonism and a half-life several times longer than spironolactone (see Table 1) [96]. Aldosterone agonism at the MR has both genomic and non-genomic effects [97].

Nongenomic MR signaling transactivates several receptor tyrosine kinases, including EGFR, platelet derived growth factor (PDGFR), and insulin-like-growth factor 1 receptor (IGF1R) [98-103]. In a series of papers between 2007 and 2012, Grossman et al. showed that aldosterone signaling at the MR increases EGFR expression and can transactivate it, and that this is blocked by spironolactone [98-103]. Importantly, EGFR and MR co-localize on the outer cell membrane of some cells.

MR agonism by aldosterone can result in phosphorylation of the intracellular portion of unliganded EGFR in the same manner as if EGFR had dimerized and bound its cognate ligand $[102,104]$. In a potentially destructive reciprocal interaction, EGFR activation by ligand increases MR transcription and translation [105] —a mutually reinforcing feedback 
loop between the EGFR and MR. The MR can be stimulated also by glucocorticoids, and this also is blocked by spironolactone. Aldosterone activates unliganded EGFR by both MR dependent, spironolactone inhibitable, and non-MR spironolactone insensitive pathways [102,106].

An interesting intersection with renal failure, glomerular mesangial proliferation is mediated in part by aldosterone activated MR transactivating EGFR [107-109].

Importantly for OPALS, in 2019, experimental work again indicating the association between EGFR and the MR showed that spironolactone decreases GB cell survival and sensitized glioma cells to the EGFR inhibitor osimertinib [110].

Spironolactone was also shown to inhibit homologous repair of ds-DNA breaks [110-113]. The MOA of this is thought to be by spironolactone's induction of xeroderma pigmentosum group $\mathrm{B}(\mathrm{XPB})$ protein degradation. XPB forms part of the multimeric transcription factor II-H related DNA repair process.

High throughput screening non-obvious drug combinations identified spironolactone as a synergistic partner drug to cisplatin and the related inhibition of homology directed DNA repair $[114,115]$. Although some studies have shown spironolactone exerts its anticancer effects by inhibiting DNA repair, thereby augmenting DNA-damaging drugs, a recent report demonstrated spironolactone's synergy with non-genotoxic EGFR inhibitor osimertinib as well as to gemcitabine in both GB and in NSCLC cells [110].

These findings, referenced above, are representative-not all inclusive- of the extensive database showing a reciprocal relationship between the MR and the EGFR, leading to the conclusion that when the action of one is desirable to block, the action of both should be blocked, a conclusion others drew in 2011 (but we have yet to act on this) [116]. Hence, if osimertinib, then spironolactone.

\title{
4. Discussion
}

This report was not a comprehensive review of the anti-cancer growth aspects that have been demonstrated for the five OPALS drugs. The references and reviewed data were just enough to show the value and pre-safety of the regimen. The works we cite here were fairly representative of recent data on these drugs' intersections with growth-driving elements of NSCLC and, to lesser extent, of GB.

\section{Conclusions}

Given the preclinical and clinical data reviewed here, in face of the usually fatal outcome of GB and of metastatic NSCLC and the eminently benign expected side effects from adjuvant OPALS, a pilot study of OPALS along with current standard treatment is warranted.

Author Contributions: All authors contributed equally. All authors have read and agreed to the published version of the manuscript.

Funding: This was unfunded research.

Institutional Review Board Statement: Not applicable.

Informed Consent Statement: Not applicable.

Data Availability Statement: All data has been included in the manuscript.

Conflicts of Interest: The authors declare no conflict of interest.

\author{
Abbreviations \\ CSC cancer stem cells \\ DHFR dihydrofolate reductase \\ GB glioblastoma \\ EGFR epidermal growth factor receptor
}


eIF4E eukaryotic translation initiation factor $4 \mathrm{E}$

HCC hepatocellular carcinoma

MMP-9 matrix metalloproteinase-9

MOA mode of action

MR mineralocorticoid receptor

MTX methotrexate

NSCLC non-small cell carcinoma

\section{References}

1. Halatsch, M.-E.; Kast, R.E.; Dwucet, A.; Hlavac, M.; Heiland, T.; Westhoff, M.-A.; Debatin, K.-M.; Wirtz, C.R.; Siegelin, M.D.; Karpel-Massler, G. Bcl-2/Bcl-xL inhibition predominantly synergistically enhances the anti-neoplastic activity of a low-dose CUSP9 repurposed drug regime against glioblastoma. Br. J. Pharmacol. 2019, 176, 3681-3694. [CrossRef] [PubMed]

2. Kast, R.E.; Karpel-Massler, G.; Halatsch, M.-E. CUSP9* treatment protocol for recurrent glioblastoma: Aprepitant, artesunate, auranofin, captopril, celecoxib, disulfiram, itraconazole, ritonavir, sertraline augmenting continuous low dose temozolomide. Oncotarget 2014, 5, 8052-8082. [CrossRef] [PubMed]

3. Kast, R.E.; Boockvar, J.A.; Brüning, A.; Cappello, F.; Chang, W.-W.; Cvek, B.; Dou, Q.P.; Duenas-Gonzalez, A.; Efferth, T.; Focosi, D.; et al. A conceptually new treatment approach for relapsed glioblastoma: Coordinated undermining of survival paths with nine repurposed drugs (CUSP9) by the International Initiative for Accelerated Improvement of Glioblastoma Care. Oncotarget 2013, 4, 502-530. [CrossRef] [PubMed]

4. Serafin, M.B.; Bottega, A.; Da Rosa, T.F.; Machado, C.S.; Foletto, V.S.; Coelho, S.S.; Da Mota, A.D.; Hörner, R. Drug Repositioning in Oncology. Am. J. Ther. 2021, 28, e111-e117. [CrossRef]

5. Palmer, A.C.; Chidley, C.; Sorger, P.K. A curative combination cancer therapy achieves high fractional cell killing through low cross-resistance and drug additivity. eLife 2019, 8. [CrossRef]

6. Grassi, G.; Grassi, M. Drug Repurposing in Human Cancers. Curr. Med. Chem. 2020, 27, 7213. [CrossRef]

7. Soria, J.-C.; Ohe, Y.; Vansteenkiste, J.; Reungwetwattana, T.; Chewaskulyong, B.; Lee, K.H.; Dechaphunkul, A.; Imamura, F.; Nogami, N.; Kurata, T.; et al. Osimertinib in UntreatedEGFR-Mutated Advanced Non-Small-Cell Lung Cancer. N. Engl. J. Med. 2018, 378, 113-125. [CrossRef]

8. Lamb, Y.N.; Scott, L.J. Osimertinib: A Review in T790M-Positive Advanced Non-Small Cell Lung Cancer. Target. Oncol. 2017, 12, 555-562. [CrossRef]

9. Brown, H.; Vansteenkiste, J.; Nakagawa, K.; Cobo, M.; John, T.; Barker, C.; Kohlmann, A.; Todd, A.; Saggese, M.; Chmielecki, J.; et al. Programmed Cell Death Ligand 1 Expression in Untreated EGFR Mutated Advanced NSCLC and Response to Osimertinib Versus Comparator in FLAURA. J. Thorac. Oncol. 2020, 15, 138-143. [CrossRef]

10. Niessen, S.; Dix, M.M.; Barbas, S.; Potter, Z.E.; Lu, S.; Brodsky, O.; Planken, S.; Behenna, D.; Almaden, C.; Gajiwala, K.S.; et al. Proteome-wide Map of Targets of T790M-EGFR-Directed Covalent Inhibitors. Cell Chem. Biol. 2017, 24, 1388-1400.e7. [CrossRef]

11. Ballard, P.; Yates, J.W.; Yang, Z.; Kim, D.-W.; Yang, J.C.-H.; Cantarini, M.; Pickup, K.; Jordan, A.; Hickey, M.; Grist, M.; et al. Preclinical Comparison of Osimertinib with Other EGFR-TKIs in EGFR-Mutant NSCLC Brain Metastases Models, and Early Evidence of Clinical Brain Metastases Activity. Clin. Cancer Res. 2016, 22, 5130-5140. [CrossRef]

12. Makhlin, I.; Salinas, R.D.; Zhang, D.; Jacob, F.; Ming, G.-L.; Song, H.; Saxena, D.; Dorsey, J.F.; Nasrallah, M.P.; Morrissette, J.J.; et al. Clinical activity of the EGFR tyrosine kinase inhibitor osimertinib in EGFR-mutant glioblastoma. CNS Oncol. 2019, 8, CNS43. [CrossRef]

13. Karpel-Massler, G.; Westhoff, M.A.; Kast, R.E.; Wirtz, C.R.; Halatsch, M.-E. Erlotinib in Glioblastoma-Lost in Translation? Anti-Cancer Agents Med. Chem. 2011, 11, 748-755. [CrossRef]

14. Chagoya, G.; Kwatra, S.G.; Nanni, C.W.; Roberts, C.M.; Phillips, S.M.; Nullmeyergh, S.; Gilmore, S.P.; Spasojevic, I.; Corcoran, D.L.; Young, C.C.; et al. Efficacy of osimertinib against EGFRvIII+ glioblastoma. Oncotarget 2020, 11, 2074-2082. [CrossRef]

15. Yang, Z.; Yang, N.; Ou, Q.; Xiang, Y.; Jiang, T.; Wu, X.; Bao, H.; Tong, X.; Wang, X.; Shao, Y.W.; et al. Investigating Novel Resistance Mechanisms to Third-Generation EGFR Tyrosine Kinase Inhibitor Osimertinib in Non-Small Cell Lung Cancer Patients. Clin. Cancer Res. 2018, 24, 3097-3107. [CrossRef]

16. Chaib, I.; Karachaliou, N.; Pilotto, S.; Servat, J.C.; Cai, X.; Li, X.; Drozdowskyj, A.; Servat, C.C.; Yang, J.; Hu, C.; et al. Co-activation of STAT3 and YES-Associated Protein 1 (YAP1) Pathway in EGFR-Mutant NSCLC. J. Natl. Cancer Inst. 2017, 109. [CrossRef]

17. Karachaliou, N.; Chaib, I.; Cardona, A.F.; Berenguer, J.; Bracht, J.W.P.; Yang, J.; Cai, X.; Wang, Z.; Hu, C.; Drozdowskyj, A.; et al. Common Co-activation of AXL and CDCP1 in EGFR-mutation-positive Non-Small Cell Lung Cancer Associated With Poor Prognosis. EBioMedicine 2018, 29, 112-127. [CrossRef]

18. Schoenfeld, A.J.; Chan, J.M.; Kubota, D.; Sato, H.; Rizvi, H.; Daneshbod, Y.; Chang, J.C.; Paik, P.K.; Offin, M.; Arcila, M.E.; et al. Tumor Analyses Reveal Squamous Transformation and Off-Target Alterations As Early Resistance Mechanisms to First-line Osimertinib in EGFR-Mutant Lung Cancer. Clin. Cancer Res. 2020, 26, 2654-2663. [CrossRef]

19. Verusingam, N.D.; Chen, Y.-C.; Lin, H.-F.; Liu, C.-Y.; Lee, M.-C.; Lu, K.-H.; Cheong, S.-K.; Ong, A.H.-K.; Chiou, S.-H.; Wang, M.-L. Generation of osimertinib-resistant cells from epidermal growth factor receptor L858R/T790M mutant non-small cell lung carcinoma cell line. J. Chin. Med. Assoc. 2021, 84, 248-254. [CrossRef] 
20. Piotrowska, Z.; Isozaki, H.; Lennerz, J.K.; Gainor, J.F.; Lennes, I.T.; Zhu, V.W.; Marcoux, N.; Banwait, M.K.; Digumarthy, S.R.; Su, W.; et al. Landscape of Acquired Resistance to Osimertinib in EGFR-Mutant NSCLC and Clinical Validation of Combined EGFR and RET Inhibition with Osimertinib and BLU-667 for Acquired RET Fusion. Cancer Discov. 2018, 8, 1529-1539. [CrossRef]

21. Nukaga, S.; Yasuda, H.; Tsuchihara, K.; Hamamoto, J.; Masuzawa, K.; Kawada, I.; Naoki, K.; Matsumoto, S.; Mimaki, S.; Ikemura, S.; et al. Amplification of EGFR Wild-Type Alleles in Non-Small Cell Lung Cancer Cells Confers Acquired Resistance to Mutation-Selective EGFR Tyrosine Kinase Inhibitors. Cancer Res. 2017, 77, 2078-2089. [CrossRef] [PubMed]

22. Chen, Z.; Chen, Y.; Xu, Z.; Chen, L.-K.; Zhang, X.; To, K.K.W.; Zhao, H.; Wang, F.; Xia, Z.; Chen, X.; et al. Osimertinib (AZD9291) Enhanced the Efficacy of Chemotherapeutic Agents in ABCB1- and ABCG2-Overexpressing Cells In Vitro, In Vivo, and Ex Vivo. Mol. Cancer Ther. 2016, 15, 1845-1858. [CrossRef] [PubMed]

23. De Gooijer, M.C.; de Vries, N.A.; Buckle, T.; Buil, L.C.; Beijnen, J.H.; Boogerd, W.; van Tellingen, O. Improved Brain Penetration and Antitumor Efficacy of Temozolomide by Inhibition of ABCB1 and ABCG2. Neoplasia 2018, 20, 710-720. [CrossRef] [PubMed]

24. Chen, C.; Cheng, C.-D.; Wu, H.; Wang, Z.-W.; Wang, L.; Jiang, Z.-R.; Wang, A.-L.; Hu, C.; Dong, Y.-F.; Niu, W.-X.; et al. Osimertinib successfully combats EGFR-negative glioblastoma cells by inhibiting the MAPK pathway. Acta Pharmacol. Sin. 2021, 42, 108-114. [CrossRef]

25. Roth, B.L.; Driscol, J. Cyproheptadine. "PDSP Ki Database". Psychoactive Drug Screening Program (PDSP); University of North Carolina at Chapel Hill: Chapel Hill, NC, USA, 2017.

26. Hogervorst, C.O.V.W.; Koppeschaar, H.P.; Zelissen, P.M.; Lips, C.J.; Garcia, B.M. Cortisol secretory patterns in Cushing's disease and response to cyproheptadine treatment. J. Clin. Endocrinol. Metab. 1996, 81, 652-655. [CrossRef]

27. Harrison, M.E.; Norris, M.L.; Robinson, A.; Spettigue, W.; Morrissey, M.; Isserlin, L. Use of cyproheptadine to stimulate appetite and body weight gain: A systematic review. Appetite 2019, 137, 62-72. [CrossRef]

28. Feng, Y.-M.; Feng, C.-W.; Chen, S.-Y.; Hsieh, H.-Y.; Chen, Y.-H.; Hsu, C.-D. Cyproheptadine, an antihistaminic drug, inhibits proliferation of hepatocellular carcinoma cells by blocking cell cycle progression through the activation of P38 MAP kinase. BMC Cancer 2015, 15, 1-13. [CrossRef]

29. Feng, Y.-M.; Feng, C.-W.; Chen, S.C.-C.; Hsu, C.-D. Unexpected remission of hepatocellular carcinoma (HCC) with lung metastasis to the combination therapy of thalidomide and cyproheptadine: Report of two cases and a preliminary HCC cell line study. BMJ Case Rep. 2012, 2012. [CrossRef]

30. Lin, Y.-H.; Hung, S.-K.; Chiou, W.-Y.; Lee, M.-S.; Shen, B.-J.; Chen, L.-C.; Liu, D.-W.; Tsai, W.-T.; Lin, P.-H.; Shih, Y.-T.; et al. Significant symptoms alleviation and tumor volume reduction after combined simultaneously integrated inner-escalated boost and volumetric-modulated arc radiotherapy in a patient with unresectable bulky hepatocellular carcinoma. Medicine 2016, 95, e4717. [CrossRef]

31. Hsieh, M.-C.; Lee, W.-H.; Wu, A.T.; Chow, J.-M.; Chang, C.-L.; Yuan, K.S.-P.; Wu, S.-Y. Cyproheptadine use in hepatocellular carcinoma. Am. J. Cancer Res. 2017, 7, 584-602.

32. Chang, H.-C.; Lin, C.-T.; Lin, W.-Y.; Yu, P.-T. Analysis of the effects of cyproheptadine on bladder cancer through big data. Am. J. Cancer Res. 2020, 10, 2114-2119.

33. Feng, Y.-M.; Feng, C.-W.; Lu, C.-L.; Lee, M.-Y.; Chen, C.-Y.; Chen, S.C.-C. Cyproheptadine significantly improves the overall and progression-free survival of sorafenib-treated advanced HCC patients. Jpn. J. Clin. Oncol. 2015, 45, 336-342. [CrossRef]

34. Paoluzzi, L.; Scotto, L.; Marchi, E.; Seshan, V.E.; O'Connor, O.A. The anti-histaminic cyproheptadine synergizes the antineoplastic activity of bortezomib in mantle cell lymphoma through its effects as a histone deacetylase inhibitor. Br. J. Haematol. 2009, 146, 656-659. [CrossRef]

35. Mao, X.; Liang, S.-B.; Hurren, R.; Gronda, M.; Chow, S.; Xu, G.W.; Wang, X.; Zavareh, R.B.; Jamal, N.; Messner, H.; et al. Cyproheptadine displays preclinical activity in myeloma and leukemia. Blood 2008, 112, 760-769. [CrossRef]

36. Harris, A.L.; Smith, I.E. Regression of carcinoid tumour with cyproheptadine. BMJ 1982, 285, 475. [CrossRef]

37. Leitner, S.P.; Greenberg, P.; Danieu, L.A.; Michaelson, R.A. Partial Remission of Carcinoid Tumor in Response to Cyproheptadine. Ann. Intern. Med. 1989, 111, 760-761. [CrossRef]

38. Moertel, C.G.; Kvols, L.K.; Rubin, J. A study of cyproheptadine in the treatment of metastatic carcinoid tumor and the malignant carcinoid syndrome. Cancer 1991, 67, 33-36. [CrossRef]

39. Kacar, S.; Hacioglu, C.; Kar, F.; Sahinturk, V.; Kanbak, G. Cyproheptadine causes apoptosis and decreases inflammation by disrupting thiol/disulfide balance and enhancing the levels of SIRT1 in C6 glioblastoma cells. Toxicol. Vitr. 2021, $73,105135$. [CrossRef]

40. Friedman, J.R.; Richbart, S.D.; Merritt, J.C.; Brown, K.C.; Nolan, N.A.; Akers, A.T.; Lau, J.K.; Robateau, Z.R.; Miles, S.L.; Dasgupta, P. Acetylcholine signaling system in progression of lung cancers. Pharmacol. Ther. 2019, 194, 222-254. [CrossRef]

41. Spindel, E.R. Cholinergic Targets in Lung Cancer. Curr. Pharm. Des. 2016, 22, 2152-2159. [CrossRef]

42. Russo, P.; Del Bufalo, A.; Milić, M.; Salinaro, G.; Fini, M.; Cesario, A. Cholinergic Receptors as Target for Cancer Therapy in a Systems Medicine Perspective. Curr. Mol. Med. 2014, 14, 1126-1138. [CrossRef]

43. Sales, M.E.; Español, A.J.; Salem, A.R.; Pulido, P.M.; Sanchez, Y.; Sanchez, F.; Martínez, P.P. Role of Muscarinic Acetylcholine Receptors in Breast Cancer: Design of Metronomic Chemotherapy. Curr. Clin. Pharmacol. 2019, 14, 91-100. [CrossRef]

44. Hsieh, H.-Y.; Shen, C.-H.; Lin, R.-I.; Feng, Y.-M.; Huang, S.-Y.; Wang, Y.-H.; Wu, S.-F.; Hsu, C.-D.; Chan, M.W. Cyproheptadine exhibits antitumor activity in urothelial carcinoma cells by targeting GSK3 $\beta$ to suppress mTOR and $\beta$-catenin signaling pathways. Cancer Lett. 2016, 370, 56-65. [CrossRef] 
45. Li, J.; Cao, B.; Zhou, S.; Zhu, J.; Zhang, Z.; Hou, T.; Mao, X. Cyproheptadine-induced myeloma cell apoptosis is associated with inhibition of the PI3K/AKT signaling. Eur. J. Haematol. 2013, 91, 514-521. [CrossRef]

46. Clark, R.B.; Perkins, J.P. Regulation of Adenosine 3':5'-Cyclic Monophosphate Concentration in Cultured Human Astrocytoma Cells by Catecholamines and Histamine. Proc. Natl. Acad. Sci. USA 1971, 68, 2757-2760. [CrossRef]

47. Falus, A. Interleukin-6 biosynthesis is increased by histamine in human B-cell and glioblastoma cell lines. Immunology 1993, 78, 193-196.

48. Skaga, E.; Skaga, I.Ø.; Grieg, Z.; Sandberg, C.J.; Langmoen, I.A.; Vik-Mo, E.O. The efficacy of a coordinated pharmacological blockade in glioblastoma stem cells with nine repurposed drugs using the CUSP9 strategy. J. Cancer Res. Clin. Oncol. 2019, 145, 1495-1507. [CrossRef]

49. Weydt, P.; Möller, T.; Labrakakis, C.; Patt, S.; Kettenmann, H. Neuroligand-triggered calcium signalling in cultured human glioma cells. Neurosci. Lett. 1997, 228, 91-94. [CrossRef]

50. Fioretti, B.; Catacuzzeno, L.; Sforna, L.; Aiello, F.; Pagani, F.; Ragozzino, D.; Castigli, E.; Franciolini, F. Histamine hyperpolarizes human glioblastoma cells by activating the intermediate-conductance $\mathrm{Ca}^{2+}$-activated $\mathrm{K}^{+}$channel. Am. J. Physiology-Cell Physiol. 2009, 297, C102-C110. [CrossRef]

51. Kast, R. Profound blocking cxcr4 signaling at multiple points using synergy between plerixafor, mirtazapine, and clotrimazole as a new glioblastoma treatment adjunct. Turk. Neurosurg. 2010, 20, 425-429. [CrossRef]

52. Thompson, E.G.; Sontheimer, H. Acetylcholine Receptor Activation as a Modulator of Glioblastoma Invasion. Cells 2019, 8, 1203. [CrossRef] [PubMed]

53. Ma, G.; Ji, D.; Qu, X.; Liu, S.; Yang, X.; Wang, G.; Liu, Q.; Du, J. Mining and validating the expression pattern and prognostic value of acetylcholine receptors in non-small cell lung cancer. Medicine 2019, 98, e15555. [CrossRef] [PubMed]

54. Stoyanov, E.; Uddin, M.; Mankuta, D.; Dubinett, S.M.; Levi-Schaffer, F. Mast cells and histamine enhance the proliferation of non-small cell lung cancer cells. Lung Cancer 2012, 75, 38-44. [CrossRef] [PubMed]

55. Wang, M.; Wei, X.; Shi, L.; Chen, B.; Zhao, G.; Yang, H. Integrative genomic analyses of the histamine H1 receptor and its role in cancer prediction. Int. J. Mol. Med. 2014, 33, 1019-1026. [CrossRef] [PubMed]

56. Kondratenko, T.Y.; Zacharova, I.V.; Kuzina, N.V.; Katukov, V.Y.; Severin, E.S. The role of histamine H1-receptors in the modula-tion of neurotransmitter receptors activity in human lung cancer. Biochem. Mol. Biol. Int. 1995, 36, 429-437. [PubMed]

57. Kondratenko, T.Y.; Zacharova, I.V.; Katukov, V.Y.; Kuzina, N.V.; Severin, E.S.; Kornilova, Z.C.; Perelman, M.I. The study of hista-mine H1- and H2-receptors in human lung cancer. Biochem. Mol. Biol. Int. 1993, 31, 399-404. [PubMed]

58. Chu, D.; Yao, D.; Zhuang, Y.; Hong, Y.; Zhu, X.; Fang, Z.; Yu, J.; Yu, Z. Azithromycin enhances the favorable results of paclitaxel and cisplatin in patients with advanced non-small cell lung cancer. Genet. Mol. Res. 2014, 13, 2796-2805. [CrossRef]

59. Lagler, H.; Kiesewetter, B.; Dolak, W.; Obermueller, M.; Simonitsch-Klupp, I.; Lukas, J.; Neuper, O.; Lamm, W.W.; Mayerhoefer, M.E.; Raderer, M. Treatment of mucosa associated lymphoid tissue lymphoma with a long-term once-weekly regimen of oral azithromycin: Results from the phase II MALT-A trial. Hematol. Oncol. 2018, 37, 22-26. [CrossRef]

60. Fassl, A.; Brain, C.; Abu-Remaileh, M.; Stukan, I.; Butter, D.; Stepien, P.; Feit, A.S.; Bergholz, J.; Michowski, W.; Otto, T.; et al. Increased lysosomal biomass is responsible for the resistance of triple-negative breast cancers to CDK4/6 inhibition. Sci. Adv. 2020, 6, eabb2210. [CrossRef]

61. Qiao, X.; Wang, X.; Shang, Y.; Li, Y.; Chen, S.-Z. Azithromycin enhances anticancer activity of TRAIL by inhibiting autophagy and up-regulating the protein levels of DR4/5 in colon cancer cells In Vitro and in vivo. Cancer Commun. 2018, 38, 1-13. [CrossRef]

62. Hirasawa, K.; Moriya, S.; Miyahara, K.; Kazama, H.; Hirota, A.; Takemura, J.; Abe, A.; Inazu, M.; Hiramoto, M.; Tsukahara, K.; et al. Macrolide Antibiotics Exhibit Cytotoxic Effect under Amino Acid-Depleted Culture Condition by Blocking Autophagy Flux in Head and Neck Squamous Cell Carcinoma Cell Lines. PLoS ONE 2016, 11, e0164529. [CrossRef]

63. Moriya, S.; Che, X.-F.; Komatsu, S.; Abe, A.; Kawaguchi, T.; Gotoh, A.; Inazu, M.; Tomoda, A.; Miyazawa, K. Macrolide antibiotics block autophagy flux and sensitize to bortezomib via endoplasmic reticulum stress-mediated CHOP induction in myeloma cells. Int. J. Oncol. 2013, 42, 1541-1550. [CrossRef]

64. Abbas, S.; Singh, S.K.; Saxena, A.K.; Tiwari, S.; Sharma, L.K.; Tiwari, M. Role of autophagy in regulation of glioma stem cells population during therapeutic stress. J. Stem Cells Regen. Med. 2020, 16, 80-89. [CrossRef]

65. Li, F.; Shuang, L.; Ji, D.; Meng, Q.; Wang, C.; Chenghong, L.; Wang, X.; Zhu, Z.; Jiang, C.; Shi, C.; et al. Azithromycin effectively inhibits tumor angiogenesis by suppressing vascular endothelial growth factor receptor 2-mediated signaling pathways in lung cancer. Oncol. Lett. 2017, 14, 89-96. [CrossRef]

66. Vandooren, J.; Knoops, S.; Buzzo, J.L.A.; Boon, L.; Martens, E.; Opdenakker, G.; Kolaczkowska, E. Differential inhibition of activity, activation and gene expression of MMP-9 in THP-1 cells by azithromycin and minocycline versus bortezomib: A comparative study. PLoS ONE 2017, 12, e0174853. [CrossRef]

67. Gong, L.; Wu, D.; Zou, J.; Chen, J.; Chen, L.; Chen, Y.; Ni, C.; Yuan, H. Prognostic impact of serum and tissue MMP-9 in non-small cell lung cancer: A systematic review and meta-analysis. Oncotarget 2016, 7, 18458-18468. [CrossRef]

68. Rajesh, Y.; Banerjee, A.; Pal, I.; Biswas, A.; Das, S.; Dey, K.K.; Kapoor, N.; Ghosh, A.K.; Mitra, P.; Mandal, M. Delineation of crosstalk between HSP27 and MMP-2/MMP-9: A synergistic therapeutic avenue for glioblastoma management. Biochim. Biophys. Acta (BBA) Gen. Subj. 2019, 1863, 1196-1209. [CrossRef]

69. Goethe, E.; Carter, B.Z.; Rao, G.; Pemmaraju, N. Glioblastoma and acute myeloid leukemia: Malignancies with striking similarities. J. Neuro-Oncol. 2017, 136, 223-231. [CrossRef] 
70. Morris, D.L.; De Souza, A.; Jones, J.A.; Morgan, W.E. High and prolonged pulmonary tissue concentrations of azithromycin following a single oral dose. Eur. J. Clin. Microbiol. Infect. Dis. 1991, 10, 859-861. [CrossRef]

71. Hannewald, P.; Maunit, B.; Muller, J.-F. Screening of DHFR-binding drugs by MALDI-TOFMS. Anal. Bioanal. Chem. 2008, 392, 1335-1344. [CrossRef]

72. Assaraf, Y.G.; Slotky, J. Characterization of a lipophilic antifolate resistance provoked by treatment of mammalian cells with the antiparasitic agent pyrimethamine. J. Biol. Chem. 1993, 268, 4556-4566. [CrossRef]

73. Reynolds, E. Vitamin B12, folic acid, and the nervous system. Lancet Neurol. 2006, 5, 949-960. [CrossRef]

74. Ben-Harari, R.R.; Goodwin, E.; Casoy, J. Adverse Event Profile of Pyrimethamine-Based Therapy in Toxoplasmosis: A Systematic Review. Drugs RED 2017, 17, 523-544. [CrossRef]

75. De Ven, E.S.-V.; Galama, J.; Vree, T.; Camps, W.; Baars, I.; Eskes, T.; Meuwissen, J.; Melchers, W. Study of treatment of congenital Toxoplasma gondii infection in rhesus monkeys with pyrimethamine and sulfadiazine. Antimicrob. Agents Chemother. 1995, 39, 137-144. [CrossRef]

76. Jansen, G.; Barr, H.; Kathmann, I.; Bunni, M.A.; Priest, D.G.; Noordhuis, P.; Peters, G.J.; Assaraf, Y.G. Multiple mechanisms of resistance to polyglutamatable and lipophilic antifolates in mammalian cells: Role of increased folylpolyglutamylation, expanded folate pools, and intralysosomal drug sequestration. Mol. Pharmacol. 1999, 55, 761-769.

77. Sharma, A.; Jyotsana, N.; Lai, C.K.; Chaturvedi, A.; Gabdoulline, R.; Görlich, K.; Murphy, C.; Blanchard, J.E.; Ganser, A.; Brown, E.; et al. Pyrimethamine as a Potent and Selective Inhibitor of Acute Myeloid Leukemia Identified by High-throughput Drug Screening. Curr. Cancer Drug Targets 2016, 16, 818-828. [CrossRef]

78. Bowcock, S.; Linch, D.; Machin, S.; Stewart, J. Pyrimethamine in the myeloproliferative disorders: A forgotten treatment? Int. J. Lab. Hematol. 1987, 9, 129-136. [CrossRef]

79. Armata, J.; Cyklis, R.; Borkowski, W. Pyrimethamine in prevention of relapses of meningeal leukemia. Report of two cases. Cancer 1978, 42, 1216-1218. [CrossRef]

80. Smyth, A.C.; Wiernik, P.H. Combination chemotherapy of adult acute lymphocytic leukemia. Clin. Pharmacol. Ther. 1976, 19, 240-245. [CrossRef]

81. Wiernik, P.H.; Schimpff, S.C.; Schiffer, C.; Lichtenfeld, J.L.; Aisner, J.; O'Connell, M.J.; Fortner, C. Randomized clinical comparison of daunorubicin (NSC-82151) alone with a combination of daunorubicin, cytosine arabinoside (NSC-63878), 6-thioguanine (NSC-752), and pyrimethamine (NSC-3061) for the treatment of acute nonlymphocytic leukemia. Cancer Treat. Rep. 1976, $60,41-53$.

82. Fritz, I.; Wagner, P.; Bottai, M.; Eriksson, H.; Ingvar, C.; Krakowski, I.; Nielsen, K.; Olsson, H. Desloratadine and loratadine use associated with improved melanoma survival. Allergy 2020, 75, 2096-2099. [CrossRef] [PubMed]

83. Fritz, I.; Wagner, P.; Broberg, P.; Einefors, R.; Olsson, H. Desloratadine and loratadine stand out among common H1-antihistamines for association with improved breast cancer survival. Acta Oncol. 2020, 59, 1-7. [CrossRef] [PubMed]

84. Verdoodt, F.; Dehlendorff, C.; Jäättelä, M.; Strauss, R.; Pottegård, A.; Hallas, J.; Friis, S.; Kjaer, S.K. Antihistamines and Ovarian Cancer Survival: Nationwide Cohort Study and In Vitro Cell Viability Assay. J. Natl. Cancer Inst. 2019, 112, 964-967. [CrossRef] [PubMed]

85. Anand, A.; Liu, B.; Giacobini, J.D.; Maeda, K.; Rohde, M.; Jäättelä, M. Cell Death Induced by Cationic Amphiphilic Drugs Depends on Lysosomal Ca2+ Release and Cyclic AMP. Mol. Cancer Ther. 2019, 18, 1602-1614. [CrossRef]

86. Ellegaard, A.-M.; Dehlendorff, C.; Vind, A.C.; Anand, A.; Cederkvist, L.; Petersen, N.H.; Nylandsted, J.; Stenvang, J.; Mellemgaard, A.; Østerlind, K.; et al. Repurposing Cationic Amphiphilic Antihistamines for Cancer Treatment. EBioMedicine 2016, 9, 130-139. [CrossRef]

87. Kölzer, M.; Werth, N.; Sandhoff, K. Interactions of acid sphingomyelinase and lipid bilayers in the presence of the tricyclic antidepressant desipramine. FEBS Lett. 2004, 559, 96-98. [CrossRef]

88. Chanas-Larue, A.; Villalpando-Rodriguez, G.E.; Henson, E.S.; Johnston, J.B.; Gibson, S.B. Antihistamines are synergistic with Bruton's tyrosine kinase inhibiter ibrutinib mediated by lysosome disruption in chronic lymphocytic leukemia (CLL) cells. Leuk. Res. 2020, 96, 106423. [CrossRef]

89. Ma, J.; Qi, J.; Li, S.; Zhang, C.; Wang, H.; Shao, L.; Yuan, X.; Sha, Q. Desloratadine, a Novel Antigrowth Reagent for Bladder Cancer. Technol. Cancer Res. Treat. 2020, 19. [CrossRef]

90. Kim, J.Y.; Kim, K.S.; Kim, I.S.; Yoon, S. Histamine Receptor Antagonists, Loratadine and Azelastine, Sensitize P-gp-overexpressing Antimitotic Drug-resistant KBV20C Cells Through Different Molecular Mechanisms. Anticancer. Res. 2019, 39, $3767-3775$. [CrossRef]

91. Le Joncour, V.; Filppu, P.; Hyvönen, M.; Holopainen, M.; Turunen, S.P.; Sihto, H.; Burghardt, I.; Joensuu, H.; Tynninen, O.; Jääskeläinen, J.; et al. Vulnerability of invasive glioblastoma cells to lysosomal membrane destabilization. EMBO Mol. Med. 2019, 11, e9034. [CrossRef]

92. Corvol, P.; Claire, M.; Oblin, M.; Geering, K.; Rossier, B. Mechanism of the antimineralocorticoid effects of spirolactones. Kidney Int. 1981, 20, 1-6. [CrossRef]

93. Gabbard, R.D.; Hoopes, R.R.; Kemp, M.G. Spironolactone and XPB: An Old Drug with a New Molecular Target. Biomolecules 2020, 10, 756. [CrossRef]

94. Karim, A. Spironolactone: Disposition, Metabolism, Pharmacodynamics, and Bioavailability. Drug Metab. Rev. 1978, 8, 151-188. [CrossRef] 
95. Reul, J.M.H.M.; De Kloet, E.R.; Van Sluijs, F.J.; Rijnberk, A.; Rothuizen, J. Binding Characteristics of Mineralocorticoid and Glucocorticoid Receptors in Dog Brain and Pituitary. Endocrinology 1990, 127, 907-915. [CrossRef]

96. Lainscak, M.; Pelliccia, F.; Rosano, G.; Vitale, C.; Schiariti, M.; Greco, C.; Speziale, G.; Gaudio, C. Safety profile of mineralocorticoid receptor antagonists: Spironolactone and eplerenone. Int. J. Cardiol. 2015, 200, 25-29. [CrossRef]

97. Krug, A.W.; Grossmann, C.; Schuster, C.; Freudinger, R.; Mildenberger, S.; Govindan, M.V.; Gekle, M. Aldosterone stimulates epider-mal growth factor receptor expression. J. Biol. Chem. 2003, 278, 43060-43066. [CrossRef]

98. Ruhs, S.; Nolze, A.; Hübschmann, R.; Grossmann, C. 30 Years of the Mineralocorticoid Receptor: Nongenomic effects via the mineralocorticoid receptor. J. Endocrinol. 2017, 234, T107-T124. [CrossRef]

99. Grossmann, C.; Krug, A.W.; Freudinger, R.; Mildenberger, S.; Voelker, K.; Gekle, M. Aldosterone induced EGFR expression: Interac-tion between the human mineralocorticoid receptor and the human EGFR promoter. Am. J. Physiol. Endocrinol. Metab. 2007, 292, E1790-E1800. [CrossRef]

100. Grossmann, C.; Gekle, M. Nongenotropic aldosterone effects and the EGFR: Interaction and biological relevance. Steroids 2008, 73, 973-978. [CrossRef]

101. Grossmann, C.; Husse, B.; Mildenberger, S.; Schreier, B.; Schuman, K.; Gekle, M. Colocalization of mineralocorticoid and EGF receptor at the plasma membrane. Biochim. Biophys. Acta (BBA) Bioenerg. 2010, 1803, 584-590. [CrossRef]

102. Grossmann, C.; Gekle, M. Interaction between mineralocorticoid receptor and epidermal growth factor receptor signaling. Mol. Cell. Endocrinol. 2012, 350, 235-241. [CrossRef] [PubMed]

103. Schreier, B.; Rabe, S.; Winter, S.; Ruhs, S.; Mildenberger, S.; Schneider, B.; Sibilia, M.; Gotthardt, M.; Kempe, S.; Mäder, K.; et al. Moderate inappropriately high aldosterone $/ \mathrm{NaCl}$ constellation in mice: Cardiovascular effects and the role of cardiovascular epidermal growth factor receptor. Sci. Rep. 2014, 4, 7430. [CrossRef] [PubMed]

104. Forrester, S.J.; Kawai, T.; O’Brien, S.; Thomas, W.; Harris, R.C.; Eguchi, S.; Elliott, K.J. Epidermal Growth Factor Receptor Transactivation: Mechanisms, Pathophysiology, and Potential Therapies in the Cardiovascular System. Annu. Rev. Pharmacol. Toxicol. 2016, 56, 627-653. [CrossRef] [PubMed]

105. Mitsuishi, Y.; Shibata, H.; Kurihara, I.; Kobayashi, S.; Yokota, K.; Murai-Takeda, A.; Hayashi, T.; Jo, R.; Nakamura, T.; Morisaki, M.; et al. Epidermal growth factor receptor/extracellular signal-regulated kinase pathway enhances mineralocorticoid receptor transcriptional activity through protein stabilization. Mol. Cell. Endocrinol. 2018, 473, 89-99. [CrossRef]

106. Ong, G.S.; Young, M.J. Mineralocorticoid regulation of cell function: The role of rapid signalling and gene transcription path-ways. J. Mol. Endocrinol. 2017, 58, R33-R57. [CrossRef]

107. Shrestha, A.; Che, R.-C.; Zhang, A.-H. Role of Aldosterone in Renal Fibrosis. Adv. Exp. Med. Biol. 2019, 1165, 325-346. [CrossRef]

108. Sheng, L.; Yang, M.; Ding, W.; Zhang, M.; Niu, J.; Qiao, Z.; Gu, Y. Epidermal growth factor receptor signaling mediates aldosterone-induced profibrotic responses in kidney. Exp. Cell Res. 2016, 346, 99-110. [CrossRef]

109. McEneaney, V.; Harvey, B.J.; Thomas, W. Aldosterone rapidly activates protein kinase D via a mineralocorticoid receptor/EGFR trans-activation pathway in the M1 kidney CCD cell line. J. Steroid Biochem. Mol. Biol. 2007, 107, 180-190. [CrossRef]

110. Sanomachi, T.; Suzuki, S.; Togashi, K.; Sugai, A.; Seino, S.; Okada, M.; Yoshioka, T.; Kitanaka, C.; Yamamoto, M. Spironolactone, a Classic Potassium-Sparing Diuretic, Reduces Survivin Expression and Chemosensitizes Cancer Cells to Non-DNA-Damaging Anticancer Drugs. Cancers 2019, 11, 1550. [CrossRef]

111. Elinoff, J.M.; Chen, L.-Y.; Dougherty, E.J.; Awad, K.S.; Wang, S.; Biancotto, A.; Siddiqui, A.H.; Weir, N.A.; Cai, R.; Sun, J.; et al. Spironolactone-induced degradation of the TFIIH core complex XPB subunit suppresses NF- $\mathrm{KB}$ and AP-1 signalling. Cardiovasc. Res. 2018, 114, 65-76. [CrossRef]

112. Kemp, M.G.; Krishnamurthy, S.; Kent, M.N.; Schumacher, D.L.; Sharma, P.; Excoffon, K.J.; Travers, J.B. Spironolactone Depletes the XPB Protein and Inhibits DNA Damage Responses in UVB-Irradiated Human Skin. J. Investig. Dermatol. 2019, 139, 448-454. [CrossRef]

113. Compe, E.; Egly, J.-M. Nucleotide Excision Repair and Transcriptional Regulation: TFIIH and Beyond. Annu. Rev. Biochem. 2016, 85, 265-290. [CrossRef]

114. Varbanov, H.P.; Kuttler, F.; Banfi, D.; Turcatti, G.; Dyson, P.J. Screening-based approach to discover effective platinum-based chemotherapies for cancers with poor prognosis. PLoS ONE 2019, 14, e0211268. [CrossRef]

115. Shahar, O.D.; Kalousi, A.; Eini, L.; Fisher, B.; Weiss, A.; Darr, J.; Mazina, O.; Bramson, S.; Kupiec, M.; Eden, A.; et al. A high-throughput chemical screen with FDA approved drugs reveals that the antihypertensive drug Spironolactone impairs cancer cell survival by inhibiting homology directed repair. Nucleic Acids Res. 2014, 42, 5689-5701. [CrossRef]

116. Rickard, A.J.; Fuller, P.J. Mineralocorticoid and Epidermal Growth Factor Receptors: Partners in Vivo. Hypertension 2011, 57, 144-145. [CrossRef] [PubMed] 